\title{
Flow cytometric analysis of an Emiliana huxleyi bloom terminated by viral infection
}

\author{
Stéphan Jacquet ${ }^{1, *}$, Mikal Heldal ${ }^{1}$, Debora Iglesias-Rodriguez ${ }^{2}$, Aud Larsen ${ }^{1}$, \\ William Wilson ${ }^{3}$, Gunnar Bratbak ${ }^{1}$ \\ ${ }^{1}$ Department of Microbiology, University of Bergen, Jahnebakken 5, 5020 Bergen, Norway \\ ${ }^{2}$ School of Biological Sciences, University of Bristol, Woodland Road, Bristol BS8 1UG, United Kingdom \\ ${ }^{3}$ Marine Biological Association, The Laboratory, Citadel Hill, Plymouth PL1 2PB, United Kingdom
}

\begin{abstract}
During a field mesocosm experiment conducted in coastal waters off western Norway, $11 \mathrm{~m}^{3}$ enclosures were filled with unfiltered seawater and enriched daily with different nitrate and phosphate concentrations in order to induce a bloom of the coccolithophorid Emiliana huxleyi under different nutrient regimes. Flow cytometry (FCM) analysis was performed 5 times $\mathrm{d}^{-1}$ in order to follow the initiation, development and termination of the bloom as well as the production of large viruslike particles (LVLPs) identified as E. huxleyi viruses (EhV). EhV production was observed first in the enclosure where $\mathrm{N}$ was in excess, and P limitation induced a lower burst size compared to nitratereplete enclosures. These observations suggest a critical role for both $\mathrm{P}$ and $\mathrm{N}$ in E. huxleyi-EhV interactions. Concomitant to EhV production, a shift was observed between the original population (coccolith-bearing cells) towards a population characterized by the same chlorophyll a (chl a) fluorescence but with lower right angle light scatter values. This population is likely to correspond to either senescent cells losing their coccoliths or cells characterized by a lower production of coccoliths possibly due to viral infection. At the end of experiment, a significant proportion of E. huxleyi had survived after the end of the bloom. This suggests either the presence of a resistant form of the coccolithophorid or a change in the dominance of different host and/or viral strains during the bloom. A periodical pattern in virus production was recorded with virus number decreasing during the second part of the day suggesting that virus production may be synchronized to the daily light cycle. Our results provide new insights towards the understanding of the relationship between a key marine species and its specific virus.
\end{abstract}

KEY WORDS: Diel variations $\cdot$ Dynamics $\cdot$ Emiliana huxleyi $\cdot$ Flow cytometry $\cdot$ Mesocosms $\cdot$ Viruses Resale or republication not permitted without written consent of the publisher

\section{INTRODUCTION}

Marine viruses are the most abundant biological particles in the sea (Bergh et al. 1989). By specifically infecting bacteria, microalgae as well as larger pelagic animals, they are likely to play critical roles in the structure and function of aquatic food webs, i.e. in the ecology and the biogeochemistry of the ocean (see

\footnotetext{
*Present address: Station INRA d'Hydrobiologie Lacustre, UMR CARTELL, BP 511, 74203 Thonon, France.

E-mail: jacquet@thonon.inra.fr
}

reviews by Furhman 1999, Wommack \& Colwell 2000). Viruses have been shown to affect nutrient cycling (almost 1/4 of organic carbon could flow through the viral shunt, Wilhelm \& Suttle 1999), bacterial and algal biodiversity and distribution (van Hannen et al. 1999), the extent of algal blooms (Castberg et al. 2001), dimethylsulfide release (Malin et al. 1998) and genetic material transfer (Miller et al. 1992). Although an increasing amount of work has been conducted on marine viruses over the last $10 \mathrm{yr}$, little is still known about their biology (life cycle) and ecology (relationships with hosts and the environment) in marine ecosystems. 
The coccolithophorid Emiliana huxleyi (Lohmann) Hay \& Mohler is a bloom-forming phytoplankter with a worldwide distribution (Gattuso \& Buddemeir 2000). At mid-latitudes, under favorable conditions, populations can reach $5 \times 10^{3}$ to $\sim 10^{5} \mathrm{cell} \mathrm{ml}^{-1}$ in late spring-early summer (Berge 1962, Bratbak et al. 1995, Brussaard et al. 1996). Its significant contribution to calcite formation, carbon transfer (Dymond \& Lyle 1985, Balch et al. 1992) and dimethylsulfide formation (Malin et al. 1992) makes this alga a major ecological player, and therefore subject to investigation of its biological and physiological capacities (Riebesell et al. 2000, Riegman et al. 2000).

Since 1993, relationships have been found between the decline of Emiliana huxleyi populations and the appearance of large virus-like particles (LVLPs) during both mesocosm experiments and coastal or oceanic bloom observations (Bratbak et al. 1993, 1995, Brussard et al. 1996). Recently, Castberg et al. (2001) identified these LVLPs as EhV (= virus specific to E. huxleyi) using a combination of flow cytometry (FCM), electron microscopy and pulse field gel electrophoresis (PFGE). However, the influence of environmental factors on the interactions between these viruses and their hosts still remains poorly understood since few studies have been concerned with topics such as the influence of light intensity, the daily light cycle or nutrient limitation on such microalgal-virus interactions (Heldal \& Bratbak 1991, Suttle et al. 1993, Wilson et al. 1996).

During a field mesocosm experiment held in coastal waters off western Norway, different nutrient enrichments of seawater were performed in large volume $\left(>10 \mathrm{~m}^{3}\right)$ enclosures in order to induce an Emiliania huxleyi bloom (Egge \& Heimdal 1994, Castberg et al. 2001). By combining sampling several times $\mathrm{d}^{-1}$ and the use of FCM, the relationship between E. huxleyi and its $E h V$ was investigated over a short time scale. The aims of this study were to answer the following questions: (1) Does nutrient limitation influence E. huxleyi-EhV interactions? (2) Does viral activity regulate bloom development or only the termination of E. huxleyi blooms? (3) Does viral infection induce physiological changes in E. huxleyi host populations? (4) Is there periodical (typically diel) activity in virus production?

\section{MATERIALS AND METHODS}

Study site and experimental set-up. The mesocosm experiment was carried out at the Marine Biological Field Station (Espeland), adjacent to Raunefjorden, $20 \mathrm{~km}$ south of Bergen (Norway), between 6 and 25 June 2000. Enclosures of $11 \mathrm{~m}^{3}$ made of thick polyethylene $(90 \%$ light penetration of photosynthetic active radiation) were mounted on floating frames that were moored to a raft in the middle of the bay. Enclosures were filled with unfiltered seawater collected from a depth of $2 \mathrm{~m}$ adjacent to the raft on 6 June, and the water was kept homogenous by means of an airlift system (more details can be found in Egge \& Asknes 1992 and Egge \& Heimdal 1994).

Nutrient enrichment and measurements. Enclosures were enriched daily (between 09:00 and 10:00 h) with nitrate (i.e. $\mathrm{NaNO}_{3}$ ) and phosphate (i.e. $\mathrm{K}_{2} \mathrm{HPO}_{4}$ ) in order to induce a bloom of Emiliana huxleyi (see Egge \& Heimdal 1994, Castberg et al. 2001). Between 6 and 11 June, $\mathrm{N}-\mathrm{NO}_{3}$ and $\mathrm{P}-\mathrm{PO}_{4}$ were added in a $\mathrm{N}$ :P ratio of 15:1 (1.5 $\mu \mathrm{M} \mathrm{N}-\mathrm{NO}_{3}: 0.1 \mu \mathrm{M}$ P-PO $\left.\mathrm{PO}_{4}\right)$ until an increase in E. huxleyi cell numbers was observed (not shown). From 12 June, Enclosure 1 (i.e. the control, hereafter referred to as Encl1) was maintained at this same daily addition; Enclosure 2 (P-depleted, Encl2) was maintained at a N:P ratio of 75:1 with daily additions of $1.5 \mu \mathrm{M} \quad \mathrm{N}^{-\mathrm{NO}_{3}}: 0.02 \mu \mathrm{M}$ P-PO $\mathrm{P}_{4}$ Enclosure $3(\mathrm{~N}-$ depleted, Encl3) was maintained at a $\mathrm{N}: \mathrm{P}$ ratio of $5: 1$ with daily additions of $0.5 \mu \mathrm{M} \mathrm{N}-\mathrm{NO}_{3}: 0.1 \mu \mathrm{M}$ P-PO $\mathrm{PO}_{4}$. Nutrient concentrations (Fig. 1) were analyzed once daily using standard methods (Strickland \& Parsons 1968) adapted to an autoanalyzer (Føyn et al. 1981) equipped with autosampling, detection and computing units from SANplus Segmented Flow Analyser (Skalar Analytic). Nutrients were measured, within a maximum of $5 \mathrm{~d}$ after sampling, from a few $\mathrm{ml}$ of seawater preserved using chloroform ( $0.8 \%$ final concentration) and stored in the dark at $4{ }^{\circ} \mathrm{C}$ prior to analysis.

Physical and environmental parameters. Temperature, salinity and oxygen concentration were measured $1 \times \mathrm{d}^{-1}$ in all enclosures using a multiparameter water quality monitor OTS, Isi Model 85 (data not shown). Solar irradiance was measured every $10 \mathrm{~min}$ using a LICOR quanta-meter (Li-cor).

Flow cytometry sample processing and analysis. For regular FCM analysis, enclosures were sampled $5 \times \mathrm{d}^{-1}$ at ca. 09:00, 13:00, 17:00, 21:00 and 01:00 h. Analyses were performed with a FACSCalibur flow cytometer (Becton Dickinson) equipped with an aircooled laser providing $15 \mathrm{~mW}$ at $488 \mathrm{~nm}$ and with standard filter set-up. The algae were analyzed from fresh samples at high rate $\left(\sim 70 \mu \mathrm{min}^{-1}\right)$ with the addition of $1 \mu \mathrm{m}$ fluorescent beads (Molecular Probes). Autotrophic groups were discriminated on the basis of their forward or right angle light scatter (FALS, RALS) and chlorophyll (and phycoerythrin for Synechococcus and cryptophyte populations) fluorescence (Fig. 2). Virus enumeration was performed on fixed (with glutaraldehyde, $0.5 \%$ final concentration) and frozen (using liquid nitrogen) samples. Once thawed at $37^{\circ} \mathrm{C}$, samples were diluted in TE (Tris-EDTA, pH 8) buffer 10 to 100 times and heated for $10 \mathrm{~min}$ at $80^{\circ} \mathrm{C}$ after staining with the DNA dye SYBR ${ }^{\mathrm{TM}}$ Green I $(1 / 20000$ 

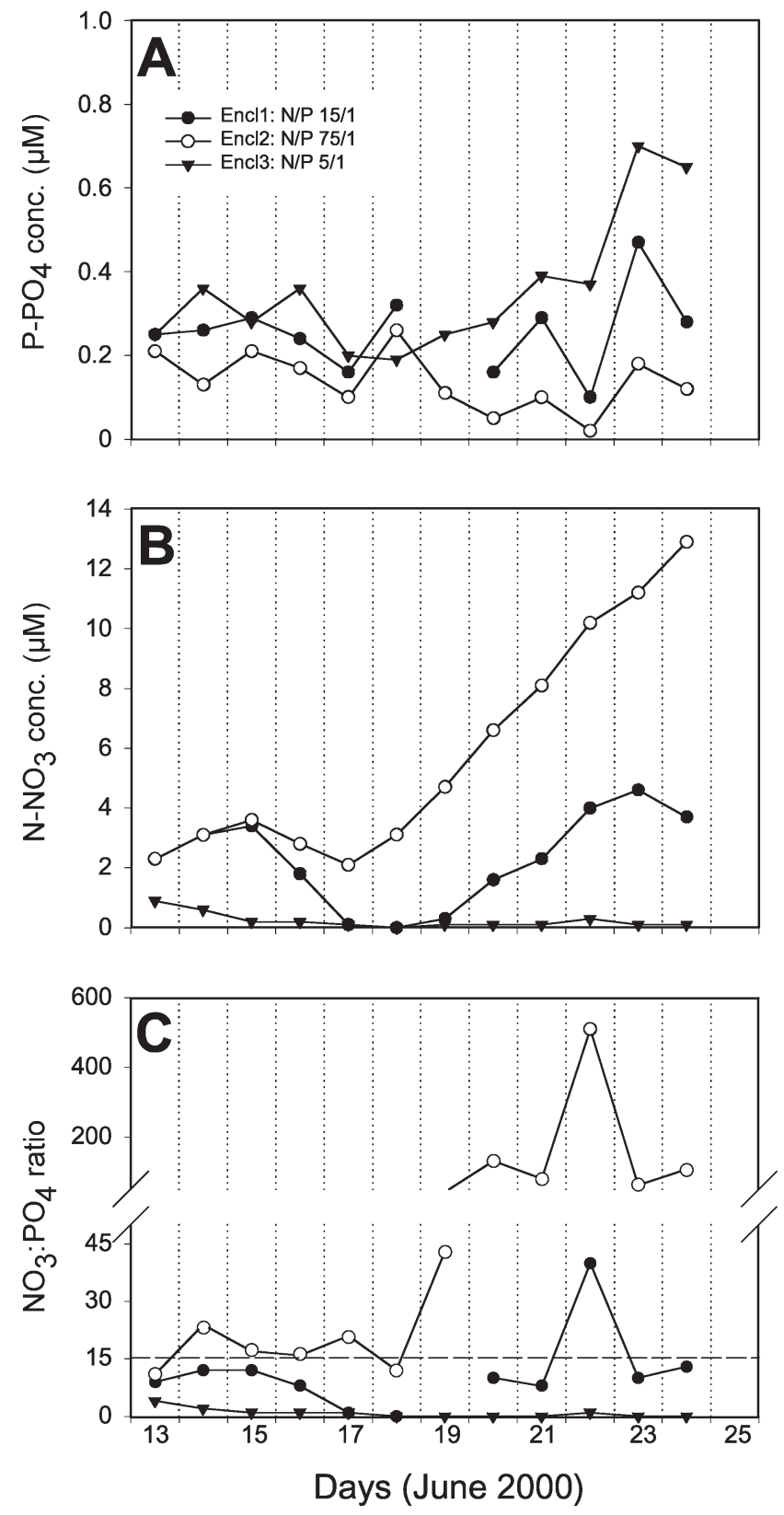

Fig. 1. Evolution of (A) $\mathrm{P}_{-} \mathrm{PO}_{4}$ and (B) $\mathrm{N}-\mathrm{NO}_{3}$ concentrations measured $1 \times \mathrm{d}^{-1}$ in Encl1 $\left(1.5 \mu \mathrm{M} \mathrm{N}-\mathrm{NO}_{3}: 0.1 \mu \mathrm{M} \mathrm{P}_{-} \mathrm{PO}_{4}\right)$, Encl2 $\left(1.5 \mu \mathrm{M} \mathrm{N}-\mathrm{NO}_{3}: 0.02 \mu \mathrm{M}\right.$ P-PO $\left.{ }_{4}\right)$ and Encl3 $(0.5 \mu \mathrm{M}$ $\mathrm{N}-\mathrm{NO}_{3}: 0.1 \mu \mathrm{M}$ P-PO $\mathrm{P}_{4}$ ) between 13 and 24 June 2000. Panel C shows the evolution of the ratio between $\mathrm{N}$ and $\mathrm{P}$. The dashed line symbolizes the Redfield ratio. No data were available for P in Encl1 on 19 June 2000

final concentration, Molecular Probes, Marie et al. 1999a). Analysis was performed at medium rate $(\sim 30 \mu \mathrm{l}$ $\left.\min ^{-1}\right)$. Viruses were discriminated on the basis of their RALS versus green DNA-dye fluorescence (Fig. 2). Listmode files were analyzed using CYTOWIN (Vaulot 1989, available at http://www.sb-roscoff.fr/Phyto/cyto. html\#cytowin) and WinMDI (Version 2.7, Trotter,
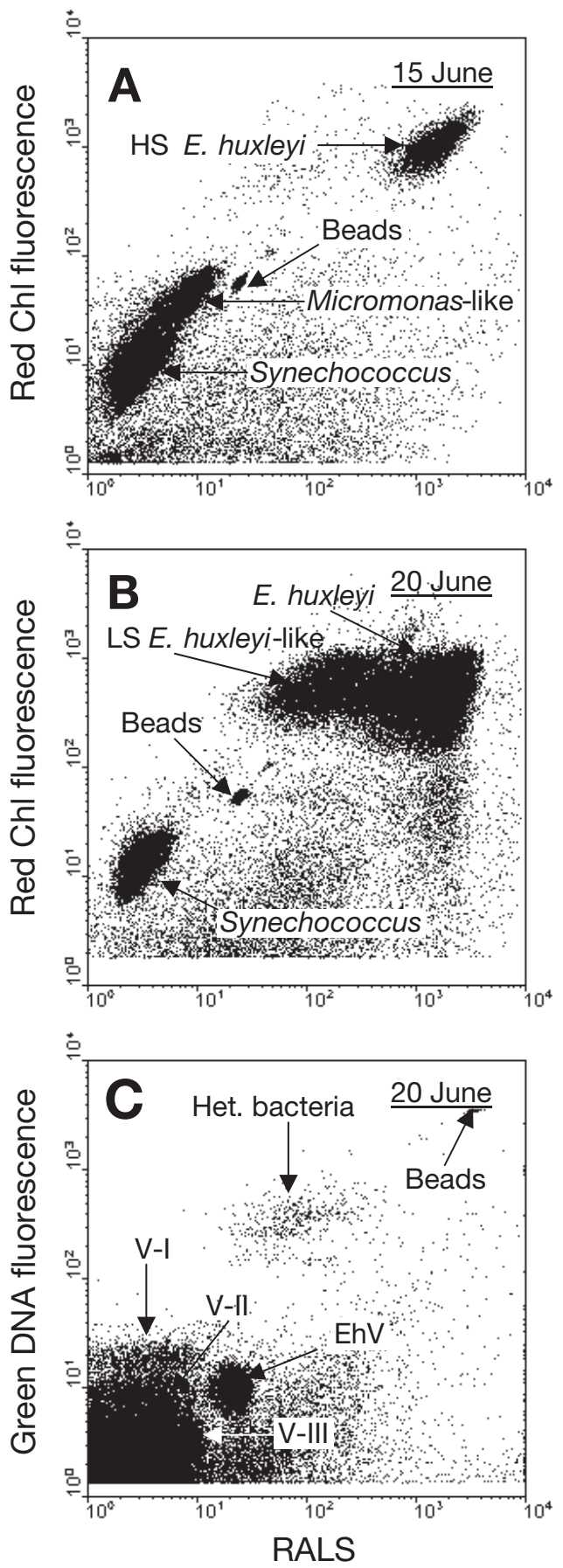

Fig. 2. Flow cytometric analysis of natural populations. On unstained samples (A,B), Synechococcus, Micromonas-like group and Emiliana huxleyi (HS for the high scatter coccolith form) were discriminated on the basis of their right angle light scatter (RALS) versus chl a red fluorescence (A, 15 June, Encl1). On panel B is shown the shift between the HS E. huxleyi and the low scatter (LS) E. huxleyi (20 June, Encl1). On samples diluted in TE buffer and stained with the DNA dye SYBR Green I (C, 20 June, Encl1), heterotrophic bacteria, E. huxleyi viruses $(E h \mathrm{~V})$ and different groups of viruses (referred to as V-I, V-II and V-III) were discriminated on the basis of the green DNA-dye complex fluorescence versus RALS. One $\mu \mathrm{m}$ beads were added to each sample before analysis 
available at http://www.bio.umass.edu/mcbfacs/flowcat.html\#winmdi).

For Emiliana huxleyi cell cycle analysis, samples were taken every $2 \mathrm{~h}$ between 15 June 09:00 h and 16 June 09:00 $\mathrm{h}$ (i.e. during the initiation of the bloom and before the population change, see below), then fixed as described in full above, frozen in liquid nitrogen and kept at $-70^{\circ} \mathrm{C}$ until analysis. Prior to analysis, samples were thawed and incubated at $37^{\circ} \mathrm{C}$ in the presence of $0.1 \mathrm{~g} \mathrm{l}^{-1}$ of a mixture of RNase A and B (Sigma R-4875 and R-5750, 1:1, w:w) for $2 \mathrm{~h}$ and then stained with SYBR Green I ( $1 / 10000$ final concentration) for $30 \mathrm{~min}$ in the dark after addition of $0.01 \%$ triton X-100 (Marie et al. 1999b). Samples were run either for $\sim 15$ min or until >10000 E. huxleyi had been counted. Acquisition was performed at medium rate $\left(\sim 30 \mu \mathrm{min}^{-1}\right)$ which allowed a good discrimination between the different cell cycle phases, G1, S and G2+M. Using this protocol, the coefficient of variation on G1 peak was always $<10 \%$. Cell cycle analyses were performed using MultiCYCLE (P. S. Rabinovitch, Phoenix Flow Systems). Cell cycle data allowed us to calculate absolute growth rate of E. huxleyi using the formula of Carpenter \& Chang (1988):

$$
\mu_{\mathrm{S}+\mathrm{G} 2+\mathrm{M}}=\frac{\int_{i=1}^{n} \ln \left[1+f_{\mathrm{S}}\left(t_{i}\right)+f_{\mathrm{G} 2+\mathrm{M}}\left(t_{i}\right)\right]}{n \times\left(T_{\mathrm{S}}+T_{\mathrm{G} 2+\mathrm{M}}\right)} \times 24
$$

where: $\mu_{\mathrm{S}+\mathrm{G} 2+\mathrm{M}}$ is an estimate of the division rate $\left(\mathrm{d}^{-1}\right)$, $n$ is the number of samples collected at fixed intervals during $1 \mathrm{~d}, T_{\mathrm{S}}+T_{\mathrm{G} 2+\mathrm{M}}(\mathrm{h})$ is the sum of the duration of $\mathrm{S}$ and $\mathrm{G} 2+\mathrm{M}$ phases, computed as twice the delay between the maxima of cells of each phase [2 $\left(t_{\mathrm{G} 2+\mathrm{Mmax}}\right.$ $-t_{\text {Smax }}$ ) $]$ and used as the terminal event $T_{\mathrm{D}}$ (see McDuff \& Chisholm 1982, Carpenter \& Chang 1988), and $f_{\mathrm{S}}\left(t_{i}\right)$ and $f_{\mathrm{G} 2+\mathrm{M}}\left(t_{i}\right)$ are the fractions of cells in $\mathrm{S}$ and $\mathrm{G} 2+\mathrm{M}$ phases at time $t_{i}$.

On 15 to 16 June, the Emiliana huxleyi loss rate $\left(\mathrm{d}^{-1}\right)$ was calculated from abundances and growth rate using the following formula:

$$
g=\mu_{\mathrm{S}+\mathrm{G} 2+\mathrm{M}}-\ln \left(N_{\mathrm{d}+1} / N_{\mathrm{d}}\right)
$$

where $N_{\mathrm{d}}$ and $N_{\mathrm{d}+1}$ are the concentrations of the population at the beginning and the end of the $24 \mathrm{~h}$ sampling period, in the absence of cell division (i.e. at 09:00 h when cells were in G1).

Phase-contrast microscopy analysis. To observe and count Emiliana huxleyi-like cells using a phasecontrast microscope, aliquots of seawater samples collected from the mesocosm treatments were concentrated or diluted as appropriate using fresh f/2 medium (Guillard \& Lorenzen 1972). Cell numbers (Fig. 3, Table 1) were determined using a standard counting chamber (Hawksley). Cell size was measured at a magnification of $400 \times$.
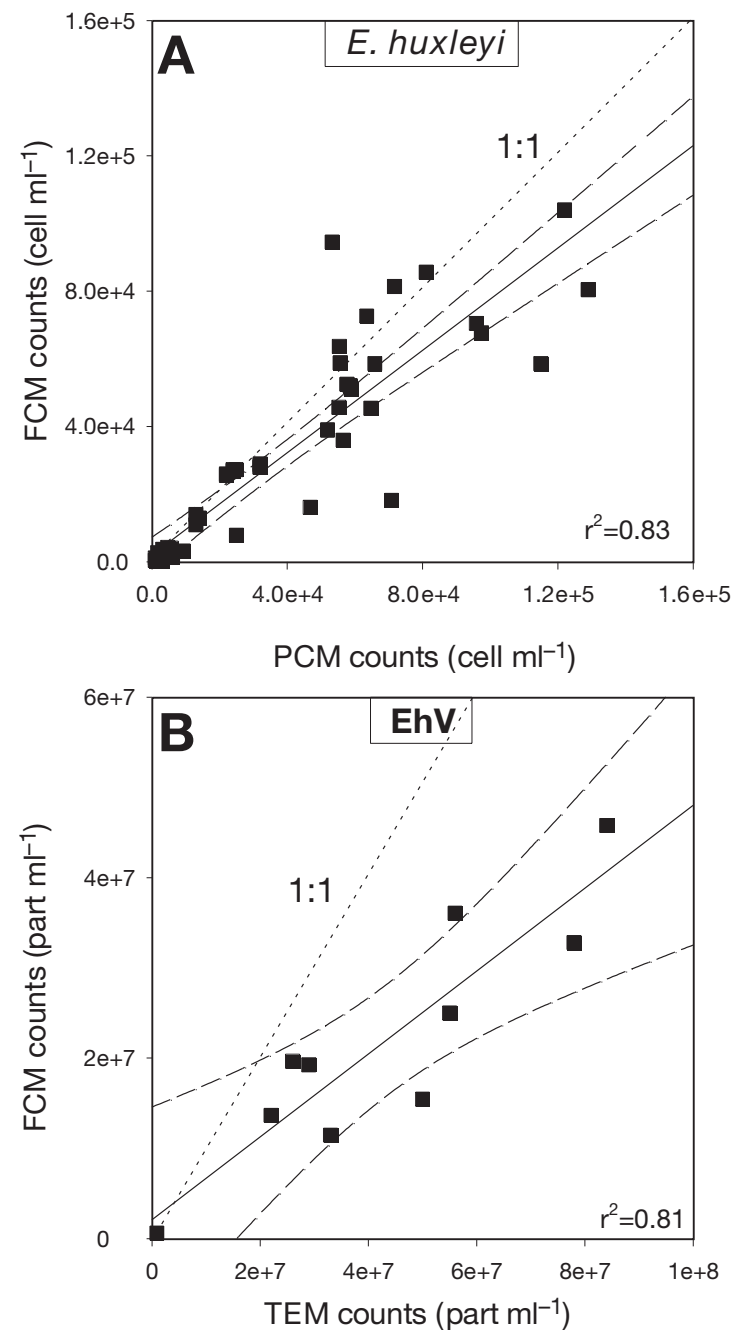

Fig. 3. (A) Relationship between the cell concentrations of HS Emiliana huxleyi determined by flow cytometry (FCM) and by phase-contrast microscope (PCM). The solid line corresponds to the linear fit to the data $\left(\mathrm{N}_{\mathrm{FCM}}=0.76 \mathrm{~N}_{\mathrm{PCM}}+1911\right.$, $\mathrm{r}^{2}=0.83, \mathrm{p}<0.01, \mathrm{n}=69$ ). (B) Relationship between the concentration of $E$. huxleyi viruses determined by flow cytometry (FCM) and by electron microscopy measurement (TEM). The solid line corresponds to the linear fit to the data $\left(\mathrm{N}_{\mathrm{FCM}}=\right.$ $0.46 \mathrm{~N}_{\mathrm{TEM}}+2.1 \times 10^{6}, \mathrm{r}^{2}=0.81, \mathrm{p}<0.01, \mathrm{n}=10$ ). The short dash curves correspond to $99 \%$ confidence intervals. The 1:1 relationship is provided for the 2 panels

Table 1. Small (3 to $5 \mu \mathrm{m})$ Emiliana huxleyi cells as percentage of the total E. huxleyi population (small cells + large cells [>5 $\mu \mathrm{m}]+$ coccolithophore-like flagellated cells) between 19 and 21 June 2000, i.e. when the bloom declined

\begin{tabular}{|lccc|}
\hline \multirow{2}{*}{ Date } & \multicolumn{3}{c|}{$\%$ small E. huxleyi cells $( \pm \mathrm{SD}, \mathrm{n}=3)$} \\
& Encl1 & Encl2 & Encl3 \\
\hline 19 June & $24 \pm 5$ & $21 \pm 6$ & $16.9 \pm 0.4$ \\
20 June & $10.6 \pm 0.5$ & $5 \pm 1$ & $7 \pm 3$ \\
21 June & $6 \pm 2$ & $13 \pm 14$ & $7 \pm 8$ \\
\hline
\end{tabular}


Transmission electron microscopy analysis. Some samples were prepared for Transmission Electron Microscopy (TEM) analysis according to Bratbak \& Heldal (1993). Briefly, samples were fixed with $2 \%$ glutaraldehyde and then harvested by centrifugation directly onto 400 mesh Ni-grids supported with carboncoated formvar film. We used an L8-70M Ultracentrifuge (Beckman) and a swing out bucket rotor (SW 41) at $40000 \mathrm{rpm}$ for $30 \mathrm{~min}$. The grids were positively stained with $2 \%$ uranyl acetate and observed in TEM (Jeol 100S) at a magnification of 10000 to 50000 (Figs. 3 \& 4). Some samples were also prepared for thin sectioning. After 2 successive centrifugations at $5000 \mathrm{rpm}$ for $10 \mathrm{~min}$, the concentrated cells were mixed with a drop of $2 \%$ alginate solution in an Eppendorf tube and the whole preparation was centrifuged for $10 \mathrm{~min}$ at $6000 \mathrm{rpm}$ (modified from Tamponnet et al. 1988). One drop of $\mathrm{CaCl}_{2} \cdot 2 \mathrm{H}_{2} \mathrm{O}$, $0.1 \mathrm{M}$, was added to the sample to polymerize the preparation. The alginate embedded cells were divided into mm size samples, washed twice in cacodylate buffer $0.1 \mathrm{M}$ for a few $\mathrm{h}$ and postfixed with $2 \% \mathrm{OsO}_{4}$ in cacodylate buffer for $20 \mathrm{~min}$. The preparations were washed in cacodylate buffer and stored at $4^{\circ} \mathrm{C}$ over night. After dehydration into a 2 step series of alcohol (70 and $95 \%$ ), cells were transferred to medium-grade LR white resin (Agar Scientific), in gelatine capsules for $12 \mathrm{~h}$. The latter step was performed twice before polymerization at $60^{\circ} \mathrm{C}$ for $24 \mathrm{~h}$. Thin sections were generated with an ultramicrotome, using Diatome diamond knife. The thin sections were put onto 100 mesh Cu-grids (thin bar grids, Agar Scientific) supported with carboncoated formvar film, stained with uranyl acetate and lead citrate. Preparations were observed in TEM (Jeol 100S) at magnifications of 10000 to 50000 (Fig. 4).

\section{RESULTS}

\section{Changes in the environment}

Measured nutrient concentrations reflected additions made throughout the study. $\mathrm{P}$ concentration remained relatively low, $<0.7 \mu \mathrm{M}$ (Fig. 1A). The phosphate concentration in Encl2 was $<0.2 \mu \mathrm{M}$ most of the time whereas it fluctuated $>0.2 \mu \mathrm{M}$ in both Encl1 and Encl3. The difference between the 3 treatments was more marked for $\mathrm{N}$ with concentration varying between 0 and $13 \mu \mathrm{M}$ (Fig. 1B). Encl3 was most of the time nearly depleted in $\mathrm{N}$ (concentration varying between 0 and $0.9 \mu \mathrm{M}$ ) in contrast to the 2 other bags. Between 13 and 15 June, the level of $\mathrm{N}$ was the same in Encl1 and Encl2 (varying between 2.3 and 3.6 $\mu \mathrm{M}$ ), but after that, the concentration remained high and increased significantly in Encl2 whereas it decreased significantly and remained lower in Encl1. Between 17

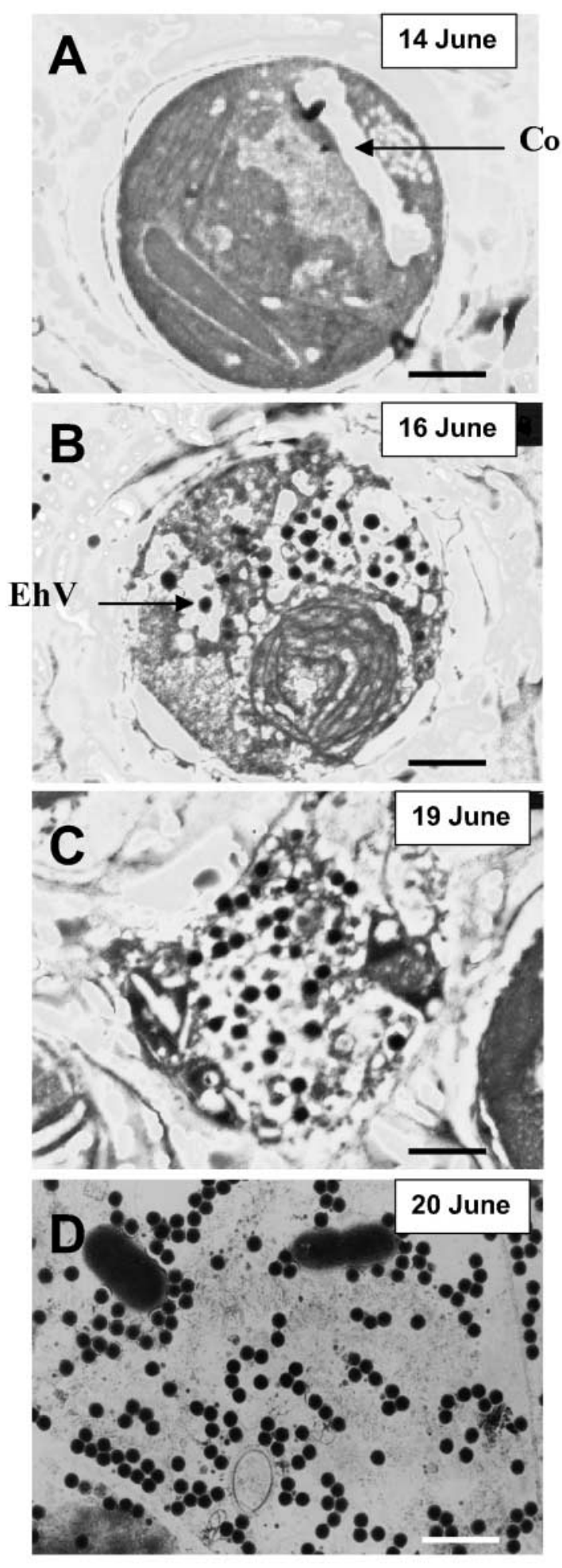

Fig. 4. Selected pictures of Emiliana huxleyi cells and viruses at different moments of the bloom sampled in Encl1, representative of typical conditions of the cells throughout the course of the study: non-infected cells (A, 14 June), infected cells (B, 16 June), lysing cells (C, 19 June) and free released viruses ( $\mathrm{D}, 20$ June). The scale bar corresponds to $1 \mu \mathrm{m}$. Co: coccolith 
and 19 June, concentration of $\mathrm{N}$ was almost identical in the Encl1 and Encl3, near the limit of detection (between 0 and $0.3 \mu \mathrm{M}$ ). Fig. 1C illustrates the N:P ratio dynamics over the course of the study suggesting that both Encl1 and Encl3 were N limited throughout the experiment whereas Encl2 was P limited after 19 June. No significant differences were recorded in salinity, temperature and oxygen concentration between the 3 bags (data not shown). Hence, these parameters were assumed to be irrelevant to explain the differences recorded between the bags. Day length was $18 \mathrm{~h}$ on average (sunrise and sunset around 05:00 and 23:00 $\mathrm{h}$ local time, respectively).

\section{FCM signature}

FCM analysis allowed us to observe very clearly both Emiliana huxleyi and LVLPs (Fig. 2). A clear correlation was found between phase-contrast microscope counts of $E$. huxleyi and the population referred to as high scatter (HS) E. huxleyi on Fig. 2A ( $\mathrm{r}^{2}=0.83$, $\mathrm{p}<0.01, \mathrm{n}=69$, Fig. $3 \mathrm{~A}$ ) confirming that this population was indeed the coccolithophorid. Seawater containing the LVLPs was collected at the end of the bloom from each enclosure (e.g. Bratbak et al. 1993). These samples were mixed together and used, after centrifugation and filtration through a $0.45 \mu \mathrm{m}$ pore size filter, to infect cultures of several microalgae available in culture (including Micromonas sp., Chrysochromulina ericina, Emiliana huxleyi, Phaeocystis pouchetti and Pyramimonas orientalis isolated in the same waters in the past). Cultures of E. huxleyi were the only ones to lyse within a few days after the addition of this seawater, supporting the idea that these viruses were specific to E. huxleyi (Table 2). Moreover, a clear correlation was found between these LVLPs as observed with TEM (the sole viral particles of this size detected between 16 and 24 June) and FCM counts (Fig. 3B). PFGE analysis (see Castberg et al. 2001) confirmed previous identification of EhV (A. Larsen et al. unpubl.). For all the above reasons, we conclude that the LVLPs can be referred to as some $E h V$. When the first signs of E. huxleyi lysis were also observed in all mesocosms, a clear shift occurred between the original population towards a population characterized by the same chl a fluorescence but lower light angle scatter values (Fig. 2B, see below) hereafter referred to as low scatter (LS) E. huxleyi.

\section{TEM analysis}

Samples were collected at different stages of the bloom (initiation, early peak, end of peak, collapse of

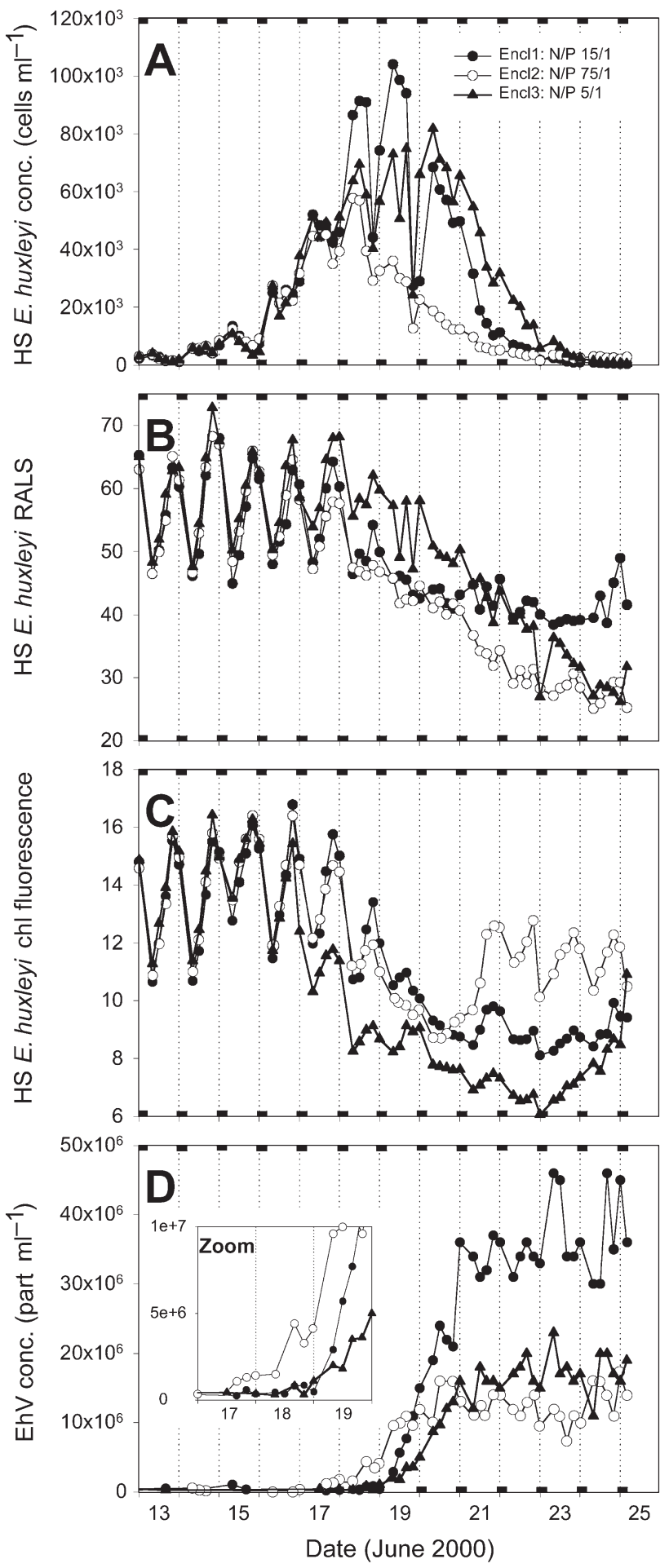

Fig. 5. Time series obtained for HS Emiliana huxleyi concentration (A), right angle light scatter RALS (B), chl a fluorescence (C) and its virus (EhV) concentration (D) using FCM between 13 and 25 June 2000 in Encl1, Encl2, Encl3. The cytometric parameters were normalized to $1 \mu \mathrm{m}$ diameter beads used as an internal reference. Dark bars symbolize the dark period of the day. The insert in panel D corresponds to a zoom on virus production between 17 and 19 June 2000 in the 3 treated bags 
Table 2. List of phytoplankton strains employed in the host range experiments. Cultures were infected with viruses sampled in the 3 enclosures on 25 June 2000. Samples from the 3 enclosures were mixed together and viruses were isolated using 2 successive centrifugations at $7500 \mathrm{rpm}$ for $10 \mathrm{~min}$ at $10^{\circ} \mathrm{C}$ and after filtration of the supernatant upon a $0.45 \mu \mathrm{m}$ pore size seringue filter. Five $\mathrm{ml}$ was added to $100 \mathrm{ml}$ cultures. + symbolizes the strains lyzed by the virus-containing isolate by comparison with - symbolizing absence of culture lysis after $7 \mathrm{~d}$. Note that all strains were isolated in Scandinavian coastal waters with the exception of Micromonas pusilla (P27 = Plymouth 27)

\begin{tabular}{|lccc|}
\hline Species & $\begin{array}{c}\text { Strain } \\
\text { code }\end{array}$ & $\begin{array}{c}\text { Culture temp. } \\
\left({ }^{\circ} \mathrm{C}\right)\end{array}$ & $\begin{array}{c}\text { Strain } \\
\text { lyzed }\end{array}$ \\
\hline Chyrsochromulina ericina & $\mathrm{IFM}$ & 15 & - \\
C. ericina & $\mathrm{Q} 17$ & 15 & - \\
Emiliana huxleyi & $\mathrm{Br}$ & 15 & + \\
E. huxleyi & $\mathrm{SC} 91$ & 15 & + \\
Micromonas pusilla & $\mathrm{P} 27$ & 15 & - \\
Phaeocystis orientalis & $\mathrm{IFM}$ & 15 & - \\
P. orientalis & $\mathrm{K} \mathrm{003}$ & 15 & - \\
Pyraminonas pouchetii & AJ 01 & 8 & - \\
\hline
\end{tabular}

the bloom) for TEM analysis, for identification of intact, infected, lysing cells and free released particles (Fig. 4). Cells of Emiliana huxleyi were identified based on the presence of coccoliths both inside and outside of the cells (Fig. 4A,B). Viruses were located inside the cytoplasm and they were rather homogenous in size, $\sim 200 \mathrm{~nm}$ in diameter. At the end of the bloom, most of the particles identified as viruses by TEM corresponded to these $200 \mathrm{~nm}$ size viruses (Fig. 4D).

\section{Population dynamics}

The short time scale variability in the coccolithophorid population was recorded by measuring the abundance of HS Emiliana huxleyi (Fig. 5A) and its cellular parameters: RALS (Fig. 5B) and chl a fluorescence (Fig. 5C) as well as the abundance of free released EhV (Fig. 5D) between 13 and 25 June. At the beginning of the study, E. huxleyi concentration was slightly $>10^{3}$ cell $\mathrm{ml}^{-1}$. After $10 \mathrm{~d}$ of daily nutrient enrichment (i.e. on 16 June), E. huxleyi cell numbers had increased significantly in all enclosures to become the main cell population detected by both FCM and TEM as well as phase-contrast microscope. By 15 June, growth rate as estimated from cell cycle data was 0.6 to $0.7 \mathrm{~d}^{-1}$. Between 13 and 16 June, no significant differences were observed between treatments suggesting that there was no specific nutrient limitation. This was also inferred from the evolution of the cells in the different phases of the cell cycle, that was almost the same in the 3 treatments (Fig. 6). After 17 June, lowest concentrations of E. huxleyi were clearly recorded in

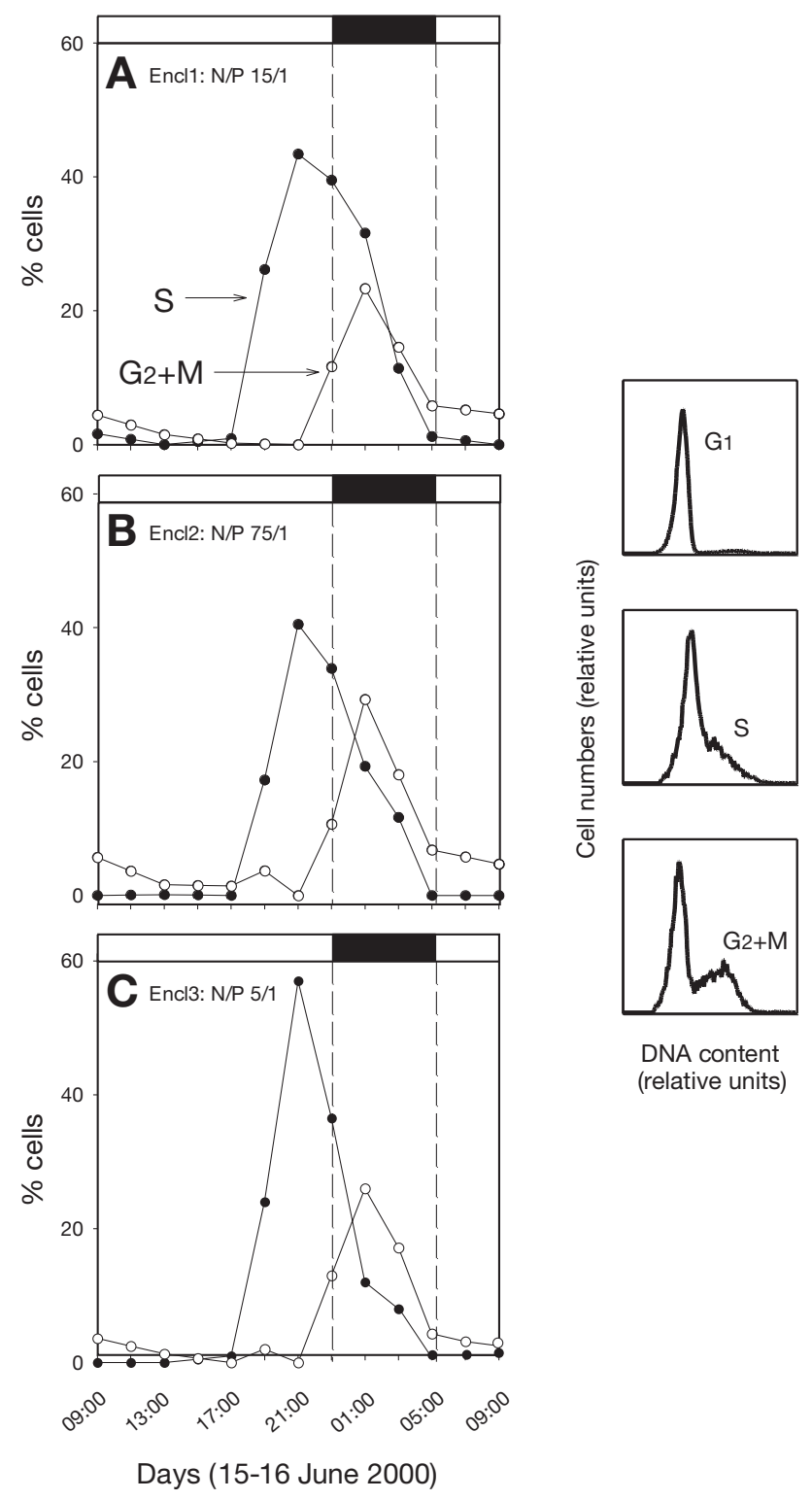

Fig. 6. Evolution of the cell cycle of HS Emiliana huxleyi during 1 diel cycle (15 to 16 June 2000) in Encl1, Encl2 and Encl3. White and dark rectangles above each panel symbolize light and dark periods, respectively. Typical DNA histograms with the evolution of cells in G1, S and G2+M are shown. Cells were stained using SYBR Green I ( $1 / 10000$ final concentration)

Encl2 (Fig. 5A). The decrease in cell concentration was very rapid and in $4 \mathrm{~d}$, algae returned to approximately the same cell number as before the initiation of the bloom, i.e. around $10^{3}$ cells $\mathrm{ml}^{-1}$ in each enclosure.

Clear diel patterns were recorded for both cell abundance and cellular parameters of Emiliana huxleyi suggesting that this population was highly synchronized to the daily light cycle (Fig. 5A-C). Patterns observed for both light scatter and chl a fluorescence 
were very similar with an increase beginning at the onset of light and maximal values recorded around dusk (this was observed from the $2 \mathrm{~h}$ sampling data on 15 to 16 June, not shown). Minimum values for cell numbers that corresponded to maximal relative values for both scatter and chl a fluorescence suggested that the population divides at night. This was confirmed by a well-phased cell cycle with a peak of cells in G2+M at night ( 01:00 h, Fig. 6). One day before the collapse of the bloom (18 June), the relative values and the amplitude of both scatter and chl a fluorescence diel rhythms decreased significantly and remained low until the end of the study. However, diel rhythms were recorded again at the end of the study, especially for chl a fluorescence, but with lower relative values (Fig. 5A-C). No photoquenching was recorded for this alga.

The increases in $E h V$ were recorded from 17 June while their host was still growing, i.e. before the point at which the Emiliana huxleyi population decreased significantly (see the zoom panel on Fig. 5D), and while host concentration ranged between $\sim 4$ and $8 \times$ $10^{4} \mathrm{cells} \mathrm{ml}^{-1}$. As for E. huxleyi abundance, the difference between the 3 treatments for EhV numbers was only obvious from 17 June, when the number of free viruses was clearly higher in Encl2. After 20 June, the concentration of $E h V$ remained relatively constant in Encl2 (around $1.5 \times 10^{7}$ viruses $\mathrm{ml}^{-1}$ ) whereas the number of these particles went on increasing in Encl1 to reach $4.5 \times 10^{7}$ viruses $\mathrm{ml}^{-1}$ on 23 June. The increase in $E h V$ in Encl3 was recorded at the same time as that in Encl1 but to a lower extent. In addition, the maximum concentration of EhV in Encl3 was almost similar to that recorded in Encl2. Burst size, i.e. the number of viruses released per lysed cell (estimated as the ratio of the maximal number of viruses produced to the maximum cell concentration reached by the specific host before cell decrease), was calculated at 400, 230 and 270 in Encl1, Encl2 and Encl3, respectively. We estimated the number of host cells killed by viral lysis from the ratio between the number of viruses produced and the burst size (see Bratbak et al. 1993 for equation details). Assuming no viral decay rate between 19 and 21 June, i.e. at the beginning of bloom decline, it was estimated that virus-induced mortality of $E$. huxleyi varied between 40 and $100 \%$ of the net total mortality $\mathrm{d}^{-1}$. Comparatively, grazing pressure was relatively weak, varying from $<0.1$ to $0.3 \mathrm{~d}^{-1}$ at the beginning of the bloom as inferred from Eq. (2) to $<0.1$ to $0.01 \mathrm{~d}^{-1}$ in the middle and in the decaying phase of the bloom as inferred from dilution experiments carried out during this mesocosm study (Evans et al. unpubl. data). Periodic patterns were observed in the abundance of $E h V$, for example, virus number decreased during the second part of the day in most cases suggesting virus infection and lysis may be directly or indirectly affected by the daily light cycle (Fig. 5D).

\section{Population change}

When the clear increase in free released $E h \mathrm{~V}$ was recorded, there was also a change in the flow cytometry signature of the Emiliana huxleyi population. The LS population (Fig. 2B) appeared first in Encl2, then in Encl1 and in Encl3 (Fig. 7A), paralleling thus

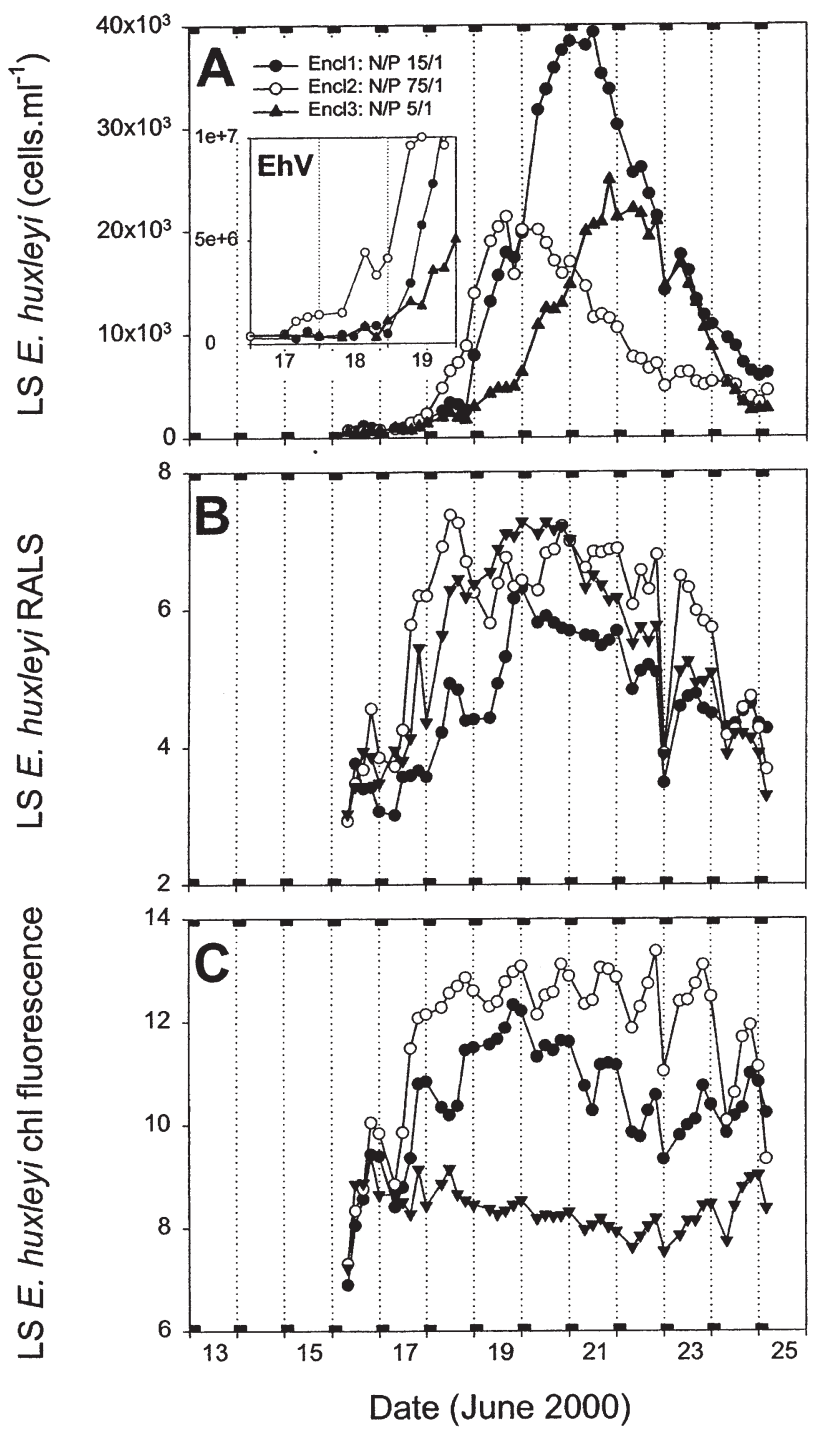

Fig. 7. Time series obtained for LS Emiliana huxleyi (A) concentration, (B) RALS and (C) chl a fluorescence using FCM between 13 and 25 June 2000 in Encl1, Encl2 and Encl3. The cytometric parameters were normalized to $1 \mu \mathrm{m}$ diameter beads used as an internal reference. The insert in panel A corresponds to a zoom on virus production between 17 and 19 June 2000 in the 3 treated bags. Symbols are as in Fig. 5 
EhV increase in each enclosure. LS population maximum concentration was almost similar, i.e. $\sim 2.2 \times$ $10^{4}$ cells $\mathrm{ml}^{-1}$ in Encl2 and Encl3 with a $2 \mathrm{~d}$ lag to reach this concentration, whereas it reached $4 \times 10^{4} \mathrm{cells} \mathrm{ml}^{-1}$ in Encl1 (Fig. 7A). Clear diel patterns were recorded for the chl a fluorescence of the LS population (towards the end) but not for RALS (Fig. 7B,C). Two morphological cell types were observed with a phase-contrast microscope. Calcifying cells decreased in size and the original E. huxleyi population began to be replaced by marginally larger coccolithophore-like flagellated cells surrounded by a lower number of coccoliths after 18 June (Table 1).

\section{DISCUSSION}

Once Emiliana huxleyi and EhV had been identified, this study demonstrated that FCM is a very useful tool to assay the short time scale dynamics of E. huxleyi and its viruses. In addition, we were able to observe the development of an autotrophic population with LS in parallel with an increase in virus production that reflected important physiological changes in the original E. huxleyi population. FCM has been recently introduced to the study of aquatic viruses with the use of very sensitive nucleic acid dyes (Brussaard et al. 1999, Marie et al. 1999a, Chen et al. 2001). Here, we demonstrate its power in the field of marine viral ecology, especially for large microalgal viruses that can be easily discriminated from bacteria or other small particles such as bacteriophages and from background noise (e.g. Castberg et al. 2001).

The main results of this study are: (1) the production of Emiliana huxleyi viruses was observed while the host population was still growing; (2) both $\mathrm{P}$ and $\mathrm{N}$ availability affected viral production; (3) virus production was accompanied by the appearance of a new active population revealing important physiological changes in the original E. huxleyi population; (4) some periodic oscillations in the production of E. huxleyi viruses were detected; and (5) a significant proportion of the original population of E. huxleyi survived after the bloom decay (or termination).

\section{Bloom dynamics}

The results of this study are comparable to those of Bratbak et al. (1993), Egge \& Heimdal (1994) and Castberg et al. (2001) for induced monospecific blooms of Emiliana huxleyi and those of Bratbak et al. (1996) and Brussaard et al. (1996) for natural blooms of the coccolithophorid both in Norwegian coastal waters and in the North Sea. It is likely that the prymnesiophyte bloomed in response to a combination of unique natural and enhanced favorable conditions. An increase of irradiance level and temperature at this period of time, a $\mathrm{P}$ control of the plankton community with a high degree of competitiveness for nutrients, appropriate salinity and a low control by microzooplankton grazing have been suggested to be the major factors. Riegman et al. (2000) showed that E. huxleyi is very competitive for light, comparable to the marine oceanic cyanobacteria Synechococcus and Prochlorococcus spp. Thus, this species has been observed to grow at low irradiance levels but also to present low sensitivity to photoinhibition, preventing the cells from photoinhibition after transport to surface layers. In the present study, we never recorded any evidence of non-photochemical quenching (decrease of chl a fluorescence), suggesting that E. huxleyi was indeed well protected from high irradiances or insensitive to light stress, likely due to efficient photoprotective mechanisms such as the xanthophyll cycle (Demmig-Adams \& Adams 1992). Clear diel cycles and large amplitude of variations recorded for cellular parameters suggested also that solar irradiance permitted E. huxleyi optimal growth. When the bloom started, the same patterns recorded for $E$. huxleyi abundance and cellular parameters (including DNA) in all bags strongly suggested that there was no clear nutrient limitation for population growth, at least until 18 June. Instead, these measurements, in addition to high population synchronization, reveal that the coccolithophorid probably grew at its maximal rate, i.e. about 1 division $d^{-1}$ (Riegman et al. 2000). The net increase in abundance observed at the beginning of the bloom could easily be explained by a lower rate for grazing pressure (ranging from 0.1 to $0.3 \mathrm{~d}^{-1}$ ) than growth rate.

\section{Viral control of the bloom}

The collapse of the bloom occurred very rapidly as observed previously (Bratbak et al. 1996, Castberg et al. 2001). It was associated to an important production of LVLPs identified as viruses specific to Emiliana huxleyi according to FCM (Fig. 2C), TEM (Fig. 4), host range experiments (Table 2) as well as PFGE (not shown). This is not the first study reporting the link between the termination of an algal bloom and virus production in seawater, especially for E. huxleyi. Bratbak et al. (1996) reported, from previous similar mesocosm experiments, that important concentrations of LVLPs were recorded when the bloom collapsed. In the North Sea, Brussaard et al. (1996a) reported that the end of an E. huxleyi bloom was associated with a high level of SVLPs and LVLPs. However, it is only recently that Castberg et al. (2001) concluded that a 
nutrient-induced E. huxleyi bloom was clearly terminated by viral lysis, with viruses unambiguously identified as EhV. This is to date, with $\mathrm{HaV}$ (= virus infecting Heterosigma akashiwo, Tarutani et al. 2000), 1 of the 2 marine viruses clearly identified as the cause of phytoplankton bloom termination. A common drawback of all these studies is that they only provided data with low temporal resolution (typically $1 \times \mathrm{d}^{-1}$ ), and so were unable to describe with precision the dynamics of specific host-virus interactions. Using a higher frequency sampling strategy (i.e. 5 samples $\mathrm{d}^{-1}$ ), we could observe that cell lysis occurred before the host population started to decrease (Fig. 5D). This suggests that the production of viruses could be associated with cell concentration, i.e. there is a threshold for the host population above which virus production is induced. Such an assumption is consistent with the observation of both E. huxleyi and its viruses before the bloom suggesting quite a steady-state relationship between virus and host. It is noteworthy however that the experiment was performed just a few weeks after a natural E. huxleyi bloom in the surrounding fjord, explaining why viruses were observed at the beginning of our experiment $\left(\sim 10^{3}\right.$ parts $\left.\mathrm{ml}^{-1}\right)$, as were E. huxleyi $\left(\sim 10^{3}\right.$ cell $\left.\mathrm{ml}^{-1}\right)$.

As mentioned above, Emiliana huxleyi blooms have been recorded in many different conditions or areas of the world's oceans. It is evident that all these blooms have occurred in very different environmental situations, which should have translated in very different cell number maxima. However, maximal concentrations recorded for E. huxleyi have always been quite similar, i.e. around $\sim 10^{5}$ cells $\mathrm{ml}^{-1}$. Viral infection and proliferation when the host reaches a certain concentration would explain the reason of such a finding. Host density dependency has been shown for example in Synechococcus populations in the Gulf of Mexico, where Suttle \& Chan (1994) determined that there was a threshold in the cyanobacterium abundance of $\sim 10^{3}$ cells $\mathrm{ml}^{-1}$, above which the concentration of infectious cyanophages increased 100-fold. In this study, virus production was recorded when the host concentration was between 4 and $8 \times 10^{4}$ cells ml $^{-1}$ (mean $\sim 6 \times$ $10^{4}$ cells $\mathrm{ml}^{-1}$ ) without a simultaneous decrease in host abundance. In a previous study, Bratbak et al. (1995) observed that virus numbers increased significantly while algal concentration was between $2 \times 10^{4}$ and $2 \times$ $10^{5}$ cells ml $\mathrm{m}^{-1}$. For all these reasons, it is proposed that E. huxleyi viruses may act essentially as the main controlling factors preventing populations from reaching very high concentrations rather than simple bloom terminating mortality agents (e.g. Larsen et al. 2001).

Data obtained at short-time intervals showed that viral infection induced the loss of the clear diel patterns for both RALS and chl a fluorescence of HS Emiliana huxleyi. This may reflect disruption of cell growth (i.e. photosynthesis processes and accumulation of intracellular carbon) and cell division because of viral replication inside the cells and lysis. Both parameters decreased markedly as previously observed for another prymnesiophyte, Phaeocystis pouchetti (Brussaard et al. 1999).

Many processes may be relevant in the reduction of scatter values since RALS is sensitive to cell size, refractive index and surface properties. It is likely that the reduced RALS was mainly due to dying cells but also partly to a decrease in coccolith production or detachment of the coccoliths during viral infection (see below). In contrast to RALS, a diel pattern was always observed in chl a fluorescence in infected cells but with lower amplitude than that observed in noninfected cells. From chl a fluorescence patterns, it was also clear that nutrient limitation affected the physiological state of the host population. Relative chl a fluorescence values and diel amplitude were found higher in the enclosure, where $\mathrm{N}$ concentrations were in excess (Encl2). Inversely, very low relative values, and almost absence of diel patterns, were observed in the N-limited enclosures. Additionally, the diel pattern in chl a fluorescence recovered sooner in the N-replete mesocosm. Our observations are consistent with the recent work of Riegman et al. (2000), who showed that the affinity of E. huxleyi for $\mathrm{N}$ is low compared to that for P. These authors suggested that, with 2 alkaline phosphatase systems, Emiliana huxleyi is an excellent competitor for $\mathrm{P}$ and is able to outcompete other algae at levels of inorganic P down to nM. E. huxleyi seems to be a poor competitor for $\mathrm{N}$ under $\mathrm{N}$ limitation. Here, FCM parameters appeared very useful as a diagnostic tool for assaying nutrient limitation of E. huxleyi and E. huxleyi infected with viruses.

Nutrient availability also affected virus-host interactions. Emiliana huxleyi virus production was observed in N-repleted Encl2 before the 2 other bags. Interestingly, the concentration of the host was the same in all treatments. It is likely that, in this enclosure, the production of E. huxleyi viruses was favored because of the surplus of nitrates. Indeed, there was no significant difference in phosphate concentration between the 3 bags on 17 and 18 June (Fig. 1A). In contrast, between 16 and 18 June, $\mathrm{N}$ were only recorded in Encl2 (Fig. 1B). It seems that EhV production was delayed in Encl1 and Encl3 because of $\mathrm{N}$ limitation on the host or more directly on $E h-E h \mathrm{~V}$. Such a high sensitivity of the EhV-E. huxleyi interaction to $\mathrm{N}$ limitation contradicts previous results that suggested that $\mathrm{P}$ limitation inhibited the development of viruses in E. huxleyi while the lack of $\mathrm{N}$ was inconsequential (Bratbak et al. 1993). These authors concluded that viruses may be more sensitive to $\mathrm{P}$ than $\mathrm{N}$ limitation because viruses have a high nucleic acid to protein ratio. In our case, although 
low $\mathrm{P}$ concentrations were always detected so that it is relatively difficult to draw any conclusion based upon comparisons between the 2 studies. However, the burst size was clearly lowest in Encl2, i.e. in the bag where $\mathrm{P}$ was always lower than in the other bags. Thus, it may possibly be due to the effect of $\mathrm{P}$ concentration on viral production, as P-replete mesocosms revealed in fine higher final abundance of $E h V$. Together, our study and that of Bratbak et al. suggest that both $\mathrm{P}$ and $\mathrm{N}$ may play a critical role in E. huxleyi virus-host interactions: P limitation would prevent virus production whereas $\mathrm{N}$ limitation would delay virus production. It may also be possible that nutrient availability may simply have allowed the host to grow faster favoring faster infection rates. More work is clearly needed to clarify all these hypotheses.

Burst size estimation of 230 to 400 viruses cell ${ }^{-1}$ were lower than previous estimates, i.e. about 400 and 500 viruses cell ${ }^{-1}$ according to Brussaard et al. (1996) and Bratbak et al. (1993), respectively. Based on our estimations and assuming no viral decay at the beginning of the bloom termination, we found that virus-induced mortality of Emiliana huxleyi varied between 40 and $100 \% \mathrm{~d}^{-1}$ (between 19 and 21 June). Often, we found a higher potential virus-induced mortality than the total net mortality ( $>100 \%$ ) although the decay rate was assumed to be 0 , which is probably not the case. At least 2 explanations can be given for this $>100 \%$ estimation. (1) The burst size may have been higher as it was previously reported for both Bratbak et al. (1993) and Brussaard et al. (1996) studies. (2) Some cells of E. huxleyi may have been still growing so that the 'real' mortality rate may have been higher than that observed. In their study, also assuming a zero decay rate, Bratbak et al. (1993) estimated that the virus-induced mortality of $E$. huxleyi accounted for 12 to $70 \%$ of net mortality (note that the same method of calculations was carried out between the 2 studies). Thus, both studies clearly suggest that viruses are mostly responsible for population mortality but also that 1 part of the algal population is likely subjected to other loss processes, typically sedimentation or grazing. As sedimentation was probably irrelevant (enclosed water was continuously mixed), grazing was likely the major remaining process responsible of cell mortality. In a parallel study, the grazing rate on E. huxleyi, based on dilution experiments, was estimated to be $0.01 \mathrm{~d}^{-1}$ on 18 June (Evans et al. unpubl. data). Thus, viruses appeared as the main factor responsible for the bloom collapse.

\section{EhV diel patterns}

Generally, EhV numbers increased during the first part of the day and decreased during the second part suggesting that the production of these particles could also be synchronized to the daily light cycle. This evidence for the existence of a diel pattern for phytoplankton viruses is in agreement with the recent view of Suttle (2000), who suggests that many algal viruses may persist in surface waters by having diel cycles of infection and lysis. Given that algae require light and display strong diel patterns for growth and division in response to the day and night cycle, it is likely that viral abundance and infectivity will equally respond as a result of sunlight irradiance (Suttle \& Chen 1992, Wilhelm et al. 1998). Thus, it is likely that virus production can occur when solar irradiance is reduced or it is dark so that viruses can contact their host in the absence of stressing environmental conditions. Viral replication may process during the day when enough light is provided for photosynthetic energy production. In addition, the repair mechanisms of the host may protect the viral DNA from solar radiation damage (Weinbauer et al. 1997). It is noteworthy here that both Emiliana huxleyi and its viruses are very sensitive to UVB radiations (Buma et al. 2000, Jacquet \& Bratbak unpubl.). Recently, Thyrhaug et al. (in press) showed that light:dark entrained cultures of the prasinophyte Pyramimonas orientalis, infected at different times in the dark period, lyse simultaneously during the day suggesting that proliferation of viral DNA is delayed until light (and thus enough energy) is available. These authors suggested that, as the lytic cycle of $P o V$ (= virus infecting Pyramimonas orientalis) is directly or indirectly light-regulated, the host's cell cycle might provide a total control over the virus proliferation. To our knowledge, these are the first data showing circadian rhythms in the number of virus particles of a marine alga.

\section{Population change}

Another interesting result of this study was the observation of the onset of a new coccolithophorid population (concomitant to virus production) that was characterized by the same level of chl a fluorescence but lower LS values than the original coccolith-bearing form of Emiliana huxleyi (Fig. 7). This FCM signature was not that typically recorded when cells lyse, which is more a clear decrease in chl a fluorescence, but was more reminiscent of what could possibly be a form of E. huxleyi with few or no coccoliths. Using a phasecontrast microscope, a shift from the coccolith-bearing form to a flagellate form bearing only a few coccoliths, had already been observed (Balch et al. 1993, Table 1). It is well known that the coccolith form (referred in the literature as C-cell) of E. huxleyi can shift towards other physiological forms, referred to as the naked 
(N-cell, i.e. without coccoliths) and flagellated (S-cell, i.e. with flagella) forms (e.g. Klaveness \& Paasche 1971), for example as a function of nutrient depletion, temperature changes, photon flux density and diel cycle (van Bleijswijk et al. 1994). However, to date, the exact conditions causing their production in nature are still to be identified. Although it is known that both naked and flagellated forms exist during blooms of $E$. huxleyi, it was not possible from our data to suggest that we were looking indeed at one of these forms. An interesting feature was that this population was actively growing as shown by the diel patterns recorded for chl a fluorescence. This FCM signature was probably not related to dying cells and we think that this population is likely to have been represented by either senescent cells losing their coccoliths or cells with fewer coccoliths that were infected by viruses. This was clear from the very low relative values recorded for RALS compared to the original population with a total absence of diel behavior for this parameter. Such an assumption also agrees with the fact that the decrease of HS E. huxleyi cell number at the end of the bloom was associated to the release of large numbers of coccoliths that resulted in milky waters inside the bags (data not shown). Coccolith undercalcification and malformation have been frequently observed both in culture and in the field (Young 1994, Riebesell et al. 2000). Cell-specific calcification rate decreases or even ceases during stationary phases of E. huxleyi growth in the laboratory (Balch et al. 1992) and in field experiments (Fernandez et al. 1993). Bleijswijk et al. (1994) reported that massive cell lysis, possibly due to nutrient depletion, viral activity or a combination of both, corresponding with the release of large numbers of coccoliths, marked the end of the bloom. From our data, it seems clear that a high correlation existed between viral production and physiological change in the host population. The main question now is whether viral production may be partly responsible for cell decalcification or coccolith loss and if so, to which degree? Also, may viral infection be responsible for the transition from coccolith-bearing cells to undercalcified E. huxleyi forms? Interestingly, 30 yr ago, Klaveness (1972) reported that senescence seems to favor the transition from $\mathrm{C}$ - to either $\mathrm{S}$ - or N-cells. Whatever the answer is, our data may provide a beginning of an explanation as to why Bratbak et al. (1995) found a negative correlation between virus production and calcification per cell in Norwegian coastal waters and why Brussaard et al. (1996) found a large quantity of Scells-like cells in the decaying phase of an E. huxleyi bloom in the North Sea. As we never observed such a shift during experimental work from infected cultures even using stressing conditions like UV radiations (Jacquet \& Bratbak unpubl. data), it clearly means that other factors are likely to intervene to explain such a change: nutrients and $\mathrm{CO}_{2}$ are good candidates (e.g. Bleijswijk et al. 1994, Riebesell et al. 2000).

\section{Persistence of the host population}

Despite the large quantity of infectious EhV recorded at the end of the bloom (as inferred from our host range experiments, Table 2), a significant proportion of both HS and LS Emiliana huxleyi populations survived after the bloom disintegration. The population remained at levels of $10^{2}$ to $10^{3}$ cells ml ${ }^{-1}$. Were the majority of these cells resistant to the viruses? Were the cells phenotypically similar during and after the bloom or might different clones coexist? Recently, Tarutani et al. (2000) reported, in the case of the harmful bloomforming phytoplankton Heterosigma akashiwo, that viral infection by $\mathrm{HaV}$ (= virus infecting Heterosigma akashiwo) influenced both the abundance and the clonal composition of the host algal species in northern Hiroshima Bay. Indeed, these workers were able to show that properties of cells in the bloom changed during the period of viral infection: $H$. akashiwo populations were dominated by cells susceptible to viruses but resistant cells were only in a low proportion during the bloom period. Their study demonstrated that viruses play a critical role in determining the clonal composition and maintaining the clonal diversity of field populations. There is no obvious reason to think that a phenotypic diversity in E. huxleyi in terms of sensitivity to viral infection or that EhVs phenotypically diverse in terms of their host specificity could not exist here. This will explain why we were always able to observe both viruses and host cells before the bloom occurs and why the host population was maintained at a non-negligible level at the end of the bloom despite a large amount of viruses in the water all around.

Acknowledgements. This study was supported by the Access to Research Infrastructures scheme (Improving Human Potential Program) from the European Union through Contract no. HPRI-CT-1999-00056, by The Research Council of Norway through project no. 121425/420, and by an individual Marie Curie fellowship granted to S.J. (HPMF-CT-199900030). The FACSCalibur flow cytometer was in part funded by a grant from The Knut and Alice Wallenberg Foundation to the Virtue program. We are grateful to Clelia Booman and Monica Martinussen (Department of Fisheries and Marine Biology, University of Bergen) for the organization of the workshop and Magnar Hagebø (Institute of Marine Research, Bergen) for nutrient data. All the workshop participants are acknowledged for helpful discussions and for the excellent atmosphere that prevailed at Espeland Station. The electron microscopy work was done at the Laboratory for Electron Microscopy, University of Bergen. Many thanks are addressed to Frede T. Thingstad (University of Bergen) for his 
critical reading of this manuscript. We are grateful to 3 anonymous reviewers that helped us to considerably improve our first attempt.

\section{LITERATURE CITED}

Balch WM, Holligan PM, Kilpatrick AK (1992) Calcification, photosynthesis and growth of the bloom-forming coccolithophore, Emiliana huxleyi. Cont Shelf Res 12:1353-1374

Balch WM, Kilpatrick KA, Holligan PM, Cucci TL (1993) Coccolith formation and detachment by Emiliana huxleyi (Prymnesiophyceae). J Phycol 29:566-575

Berge G (1962) Discoloration of the sea due to Coccolithus huxleyi bloom. Sarsia 6:27-40

Bergh O, Borsheim KY, Bratbak G, Heldal M (1989) High abundances of viruses found in aquatic environments. Nature 340:467-468

Bleijswijk JDL, Kempers RS, van der Wal P, Westbroek P, Egge JK, Lukk T (1994) Standing stocks of PIC, POC, PON and Emiliana huxleyi coccospheres and coccoliths in sea water enclosures with different phosphate loadings. Sarsia 79:307-317

Bratbak G, Heldal M (1993) Total count of viruses in aquatic environments. In: Kemp PF, Sherr BF, Sherr EB, Cole JJ (eds) Handbook of methods in aquatic microbial ecology. Lewis Publishers, Boca Raton, FL, p 135-138

Bratbak G, Egge JK, Heldal M (1993) Viral mortality of the marine alga Emiliana huxleyi (Haptophyceae) and termination of algal blooms. Mar Ecol Prog Ser 93:39-48

Bratbak G, Levasseur M, Michaud S, Cantin G, Fernandez E, Heimdal BR, Heldal M (1995) Viral activity in relation to Emiliana huxleyi blooms: a mechanism of DSMP release? Mar Ecol Prog Ser 128:133-142

Bratbak G, Wilson W, Heldal M (1996) Viral control of Emiliana huxleyi blooms? J Mar Syst 9:75-81

Brussaard CPD, Kempers RS, Kop AJ, Riegman R, Heldal M (1996) Virus-like particles in a summer bloom of Emiliana huxleyi in the North Sea. Aquat Microb Ecol 10:105-113

Brussaard CPD, Thyrhaug R, Marie D, Bratbak G (1999) Flow cytometric analyses of virus infection in two marine phytoplankton species, Micromonas pusilla (Prasinophyceae) and Phaeocystis pouchetti (Prymnesioiphyceae). J Phycol 35:941-948

Buma AGJ, Oijen TV, van de Poll W, Veldhuis MJW, Gieskes WWC (2000) The sensitivity of Emiliana huxleyi (Prymnesiophyceae) to ultraviolet B radiation. J Phycol 36: 296-303

Carpenter EJ, Chang J (1988) Species-specific phytoplankton growth rates via diel DNA synthesis cycles. I. Concept of the method. Mar Ecol Prog Ser 43:105-111

Castberg T, Larsen A, Sandaa RA, Brussaard CPD and 5 others (2001) Microbial population dynamics and diversity during a bloom of the marine coccolithophorid Emiliana huxleyi (Haptophyta). Mar Ecol Prog Ser 221:39-46

Chen F, Lu JR, Binder BJ, Liu YC, Hodson RE (2001) Application of digital image analysis and flow cytometry to enumerate marine viruses stained with SYBR Gold. Appl Environ Microbiol 67:539-545

Demming-Adams B, Adams WW (1992) Photoprotection and other responses of plants to light stress. Annu Rev Plant Physiol Plant Mol Biol 7:1-116

Dymond J, Lyle M (1985) Flux comparisons between sediments and sediment traps in the eastern tropical Pacific: implications for atmospheric $\mathrm{CO}_{2}$ variations during the Pleistocene. Limnol Oceanogr 30:699-712

Egge JK, Asknes DL (1992) Silicate as regulating nutrient in phytoplankton competition. Mar Ecol Prog Ser 83:281-289

Egge JK, Heimdal BR (1994) Blooms of phytoplankton including Emiliana huxleyi (Haptophyta). Effects of nutrient supply in different N:P ratios. Sarsia 79:333-348

Fernandez E, Boyd P, Holligan PM, Harbour DS (1993) Production of organic and inorganic carbon within a largescale coccolithophore bloom in the northeast Atlantic Ocean. Mar Ecol Prog Ser 97:271-285

Føyn L, Magnussen M, Seglem K (1981) Automatic analysis of nutrients with on-line data processing: a presentation of the construction and functioning of the system used at the Institute of Marine Research. Fisken Havet Serie B 4:1-39

Furhman JA (1999) Marine viruses and their biogeochemical and ecological effects. Nature 399:541-548

Gattuso JP, Buddemeir RW (2000) Calcification and $\mathrm{CO}_{2}$. Nature 407:311-312

Guiilard RRL, Lorenzen CJ (1972) Yellow-green algae with chlorophyllide c. J Phycol 8:10-14

Heldal M, Bratbak G (1991) Production and decay of viruses in aquatic environments. Mar Ecol Prog Ser 72:205-212

Klaveness D (1972) Coccolithus huxleyi (Lohl.) Kamptn. II. The flagellate cell, aberrant cell types, vegetative propagation and life cycles. Br Phycol J 7:309-318

Klaveness D, Paasche E (1971) Two different Coccolithus huxleyi cell types incapable of coccolith formation. Arch Mikrobiol 75:382-385

Larsen A, Castberg T, Sandaa RA, Brussaard CPD and 6 others (2001) Population dynamics and diversity of phytoplankton bacteria and viruses in a seawater enclosure. Mar Ecol Prog Ser 221:47-57

Malin G, Turner SM, Liss PS (1992) Sulfur: the plankton/ climate connection. J Phycol 28:590-597

Malin G, Wilson WH, Bratbak G, Liss PS, Mann NH (1998) Elevated production of dimethylsulfide from viral infection of cultures of Phaeocystis pouchetii. Limnol Oceanogr 43:1389-1393

Marie D, Bruussard CPD, Bratbak G, Vaulot D (1999a) Enumeration of marine viruses in culture and natural samples by flow cytometry. Appl Environ Microbiol 65:45-52

Marie D, Brussaard CPD, Partensky F, Vaulot D (1999b) Flow cytometric analysis of phytoplankton, bacteria and viruses. In: Robinson JP, Darzynkiewicz Z, Dean P, Orfao A, Rabinovitch $\mathrm{P}$, Tanke $\mathrm{H}$, Wheeless L (eds) Current protocols in cytometry. John Wiley \& Sons, New York, p 11.11.1-11.11.15

McDuff RE, Chisholm SW (1982) The calculation of in situ growth rates of phytoplankton populations from fractions of cells undergoing mitosis: a clarification. Limnol Oceanogr 27:783-788

Miller RV, Ripp S, Replicon J, Ogunseitan OA, Kokjohn TA (1992) Virus-mediated gene transfer in freshwater environments. In: Gauthier JM (ed) Gene transfers and environment. Springer-Verlag, Berlin, p 51-62

Riebesell U, Zondervan I, Rost B, Tortell PT, Zeebe RE, Morel FFM (2000) Rising atmospheric $\mathrm{CO}_{2}$ slows down marine planktonic calcification. Nature 407:364-367

Riegman R, Stolte W, Noordeloos AAM, Slezak D (2000) Nutrient uptake and alkaline phosphatase (EC 3:1:3:1) activity of Emiliana huxleyi (Prymnesiophyceae) during growth under $\mathrm{N}$ and $\mathrm{P}$ limitation in continuous cultures. J Phycol 36:87-96

Strickland JDH, Parsons TR (1968) A practical handbook of seawater analysis. Bull Fish Res Board Can 167:1-34

Suttle CA (2000) Ecological, evolutionary, and geochemical consequences of viral infection of cyanobacteria and eukaryotic algae. In: Hurst CJ (ed) Viral ecology. Academic Press, San Diego, CA, p 247-296 
Suttle CA, Chan AM (1994) Dynamics and distribution of cyanophages and their effect on marine Synechococcus spp. Appl Environ Microbiol 60:3167-3174

Suttle CA, Chen F (1992) Mechanisms and rates of decay of marine viruses in seawater. Appl Environ Microbiol 58: 3721-3729

Suttle CA, Chan AM, Cheng F, Garza DR (1993) Cyanophages and sunlight: a paradox. In: Guerrero R, PedrósAlió C (eds) Trends in microbial ecology. Spanish Society for Microbiology, Barcelona, p 303-307

Tamponnet C, Barbotin JN, Piton F (1988) A quick preparative method for electron microscopy observations of delicate objects using alginate embedding medium. Stain Technol 63:155-158

Tarutani K, Nagasaki K, Yamaguchi M (2000) Viral impacts on total abundance and clonal composition of the harmful bloom-forming phytoplankton Heterosigma akashiwo. Appl Environ Microbiol 66:4916-4920

Thyrhaug R, Larsen A, Brussaard CPD, Bratbak G (in press) Is virus production in marine phytoplankton cell-cycle dependent? J Phycol

van Bleijswijk JDL, Kempers R, Veldhuis MJ, Westbroek (1994) Cell and growth characteristics of types A and B of Emiliana huxleyi (Prymnesiophyceae) as determined by flow cytometry and chemical analyses. J Phycol 30:230-241

van Hannen EJ, Zwart G, van Agterveld MP, Gons HJ, Ebert J, Laanbroek HJ (1999) Changes in bacterial and eukary-

Editorial responsibility: William Li, Dartmouth, Nova Scotia, Canada otic community structure after mass lysis of filamentous cyanobacteria associated with viruses. Appl Environ Microbiol 65:795-801

Vaulot D (1989) CytoPC: processing software for flow cytometric data. Signal Noise 2:8

Weinbauer MG, Wilhelm SW, Suttle CA, Garza DR (1997) Photoreactivation compensates for UV damage and restores infectivity to natural marine viruses communities. Appl Environ Microb 63:2200-2205

Wilhelm SW, Suttle CA (1999) Viruses and nutrient cycles in the sea. Bioscience 49:781-788

Wilhelm SW, Weinbauer MG, Suttle CA, Jeffrey WH (1998) The role of sunlight in the removal and repair of viruses in the sea. Limnol Oceanogr 43:586-592

Wilson HW, Carr NG, Mann NH (1996) The effect of phosphate status the kinetics of cyanophage infection in the oceanic cyanobacterium Synechococcus sp. WH 7803. J Phycol 32:506-516

Wommack KE, Ravel J, Hill RT, Chun J, Colwell RR (1999) Population dynamics of Chesapeake Bay virioplankton: total community analysis by pulsed-field gel electrophoresis. Appl Environ Microb 65:231-240

Wommack KE, Colwell RR (2000) Virioplankton: viruses in aquatic ecosystems. Microbiol Rev 64:69-114

Young JR (1994) Variation in Emiliania huxleyi coccolith morphology in samples from the Norwegian EHUX Experiment, 1992. Sarsia 79:417-425

Submitted: July 9, 2001; Accepted: January 4, 2002

Proofs received from author(s): February 27, 2002 